$\frac{\text { DE }}{\text { DE GRUYTER }}$ OPEN

\title{
A GENDER AND MARITAL STATUS ANALYSIS OF HOUSEHOLD INCOME IN A LOW-INCOME TOWNSHIP
}

\section{Steven Henry DUNGA*}

North-West University, South Africa

\begin{abstract}
The analysis of income at household level is highly important for understanding the poverty and for supporting the efforts to deal with poverty. Poverty measures can be calculated from a multitude of approaches. A common approach is to use household income and draw a minimum level of income required for a household to be considered above or below poverty. This paper looked at income at household level from a gender perspective and a marital status perspective in order to draw conclusions of the nature of household's characteristics that are associated with higher or lower income as a proxy for poverty. Based on data collected in a low income township in South Africa, the regression analysis was applied to investigate the differences between different marital statuses and gender and how they are associated with different levels of income. The regression results reveal that female headed households have, on average, lower incomes compared to male headed households, and also, that married heads of households have higher incomes compared to the single, divorced, and widowed. The widowed had the lowest average income.
\end{abstract}

JEL classification: 132

Keywords: poverty, measurements, gender, marital status, income

\section{Introduction}

Poverty has become an operative word for most researchers and development practitioners and sometimes requires no definition. To assume that there is a consensus in the understanding of what poverty means is however erroneous. The fact that a poor person in one country may not be considered poor in another country, or the fact that there are households without income that are not poor, points to the differences in the

\footnotetext{
* Corresponding author. Address: North-West University, Vaal Triangle Campus

P. O. Box 1174, Vanderbijlpark, South Africa, Tel. 016 910-3372, Email:

Steve.Dunga@nwu.ac.za
} 
understanding and hence the definition of poverty. In the preface of Sen, (1981) Essay on Poverty and Famines he points out that 'not everything about poverty is quite so simple. Even the identification of the poor and the diagnosis of poverty may be far from obvious when we move away from extreme and raw poverty' The analysis of household income at household level is thus an important aspect in the understanding of poverty and efforts to deal with human deprivation and poverty. Dollar and Kraay (2000) argued in their study that at national level income growth proxied by GDP growth can reduce poverty. At micro level poverty measures can be calculated from a multitude of approaches (Ravallion, 1996:5 2001; Rio Group, 2006:35). A common approach is to use household income and draw a minimum level of income required for a household to be considered poor or non-poor (Ravallion 1996). There is however a weakness in using income especially in households that are involved in subsistence farming. This however remains a better and easier method. Expenditure method is also linked to the income method, where households are asked on how much they spend, this suffers from similar weaknesses as those of the income method (Meyer \& Sullivan, 2012). However, assets can also be used to calculate household poverty or wellbeing (Barrett \& Carter, 2006; Brandolini, et al. 2010) The use of income however become easy to compare situations and an absolute poverty line is a more agreed upon postulation among the many measures that exist the weaknesses notwithstanding. This paper uses income due to the limitation of the data collected in the survey, however it sets the starting point for subsequent studies in the same area that will build on the results to use more robust measures of poverty. The theories of poverty attempt to explain the origins and the causes of poverty and hence make room for better ways to circumvent the controversies surrounding the measures, but for purposes of this paper, that debate is not pursued. In this paper an analysis of the theories of poverty and the perceptions of poverty will be done in the literature review section only in a nutshell to make cognizance of the existence of the debate and how it informs the measures of poverty used in an analysis. The epistemology and the method of the data analysis will be explained in section three of the paper. The rest of the paper is organized as follows, section two is the literature review, and section three is the methodology and description of the data collection process.

The results and discussion are presented in section four and the last section presents the conclusion.

\section{Literature Review}

The measures of poverty have evolved over time from the basic income and expenditure approaches to now include approaches that are not easily monetized or quantified. The changes have been due to the developments that have taken place in the definitions of poverty and what needs to be included in understanding the Phenomenon. A good example to the evolution in the understanding of poverty may include the advent of the multidimensional poverty measurement (Alkire \& Foster, 2013; Alkire, 2009) Understanding poverty and its antecedents is therefore an ever changing process as more and more approaches are discovered and incorporated into the main stream literature of poverty (Ravallion 1991; Meyer \& Sullivan, 2012:112; Atkinson et al 1995, Alkire et al. 2015). Poverty has been considered to have a gender dimension to it as women are considered to be more likely fall into poverty 
than their male counterparts (Zick \& Smith, 1991). Other vulnerable groups which are in a sense more vulnerable than women include children and the disabled. There are a number of studies that have also linked marital status to poverty or even life longevity (Gove, 1973; Kobrin \& Hendershot, 1977; Trovato \& Lauris, 1998; Zick \& Smith, 1991). The reasoning behind the gender based income differentials is ubiquitous in the data emanating from the centuries old discrimination against women in all spheres of mankind, be-it in education, or in labour participation and even in the preference of boys to girls in the upbringing process. The gender disparity has changed substantially in most countries especially in the first world. The studies that looked at marital status differential however have pointed at different factors other than those of discrimination to be some of the factors that explain the differences. A study by Zick and Smith (1991) looked at the effect of marital transition, poverty and gender on mortality. The mortality aspect is not of interest in this paper although the logic behind the results found in Zick and Smith may also make a lot of sense in understanding income differentials in gender and marital status.

In looking at the importance of marital status categorization as a determinant of poverty, it is worth noting that marriage in the $21^{\text {st }}$ century is not as popular as it was in the previous century, and divorce has become more acceptable than before (Mergenhagen, et al., 1985). Reasons to the acceptance of divorces as a new normal may be found in other disciplines and not necessarily in economics. Data from national surveys show that there are currently more divorces than previous decades and fewer marriages than previous years (Society at a glance 2016; STATSSA 2014). A report by OECD shows that marriage rate defined as Crude marriage Rates are at their lowest in most of the OECD countries. CMR is defined as number of marriages per 1000 people, it is at an average of 4.6 for the OECD countries. However divorces also defined as number per 1000 people has reached an all-time high increasing by over $50 \%$ for the average OECD countries between 1970 and 2012 (Society at a glance 2016) Although economic explanations maybe present in the understanding. A bold guess would be that women used to rely on men for economic survival, they still do in developing countries, and hence marriage was a way out of poverty. In the modern days women are at the same level as men in most cases and hence people marry for other reason other than money, or do they? The claim that women are on the same level as men may be overstating the fact. There has been a lot of progress made especially in the developed world, but the same is not the case in developing countries, especially in the sub-Saharan Africa.

\subsection{Gender and poverty}

There is a vast body of literature on the link between gender and poverty (Jackson, 1998; Chant, 2006; 2008). The understanding of gendered poverty is not as straight forward as the proclamation that women are poorer than men, or that women are more venerable to poverty than men, it is beyond the materialistic thinking. Cecile Jackson in (1998) argued as to whether the discussion should be women and poverty or gender and wellbeing? Her argument was that the issue is beyond materials. She stated that "I have noted the tendency in development discourses to represent gender issues in development as variants of poverty problems and to reduce gender disadvantage to a claim that women are over-represented among the 
poor" This to her is a misrepresentation of the issue. Although it can be agreed that the over representation is true, her argument is that, that's not all, there is more to the gendered poverty discourse as is well document by works of Chant (Chant, 2006; Chant, 2008). Women face poverty in more ways than men and women's responsibilities in dealing with poverty may come from angles that are akin to men.

\subsection{Marital status and poverty}

The marital status connection to poverty maybe derived from a number of factors that are associated with marriage. Zick and Smith (1991) in their research on the relationship between marital status and death argued that married people live longer than the other categories. The higher advantages of the married people relative to the other categories are based on two main explanations. The first is that healthier and in the same reasoning, successful people are more likely to be selected for long term relationships. The other explanation is that marriage encourages people to live a good and acceptable life style. This is enforced by a network of relatives that come about due to marriage (Helsing, et al. 1981:808; Zick, Smith, 1991). It can be extended in the same line of thinking that people that enter into marriage are more likely to be those with a stable flow of income possibly with a job and a good level of education. This is based on what I would term the natural selection process. If a person, especially a man is not able to prove ability to provide enough for survival or sustainability, the chance that they will be accepted or selected into marriage or long term relationship is very small. It is not non-existent, but it is very small. This may explain the expectation therefore that those in marriage are more likely to be outside the poverty bracket much more than those that are not married. In that line of argument therefore it is not the marital status itself that is responsible of the income level. Although with the second line of think, the enforced good behavior hypothesis, marriage may be responsible for higher levels of income.

Marital status however can be categories into more than married and single categories. In the not married categories, there are more categories, both post and pre marriage categories.

\section{Methodology}

Data used in this study were collected in Boipatong Township in 2013. A household survey was administered to 300 households. The sample size was arrived at based on previous studies that used a similar sample size and came up with valid results (Dubihlela, et al 2014; Sekhampu, 2013) Households were randomly selected from a map of the area, and where a house that was pre-selected was not found on the site, the next house used in its place. Heads of households were interviewed on a number of issues including their income level gender and marital status. This study decided to isolate the marital status of the heads of household and gender of the heads of household and regress them with income. This is important as most models have used a combination of many demographic characteristics and hence become difficult to isolate the importance of gender and marital status. The importance of isolating gender and marital status is the fact that there have been studies that have shown 
that men earn more than women. An IMF by Kinoshita and Guo, (2015) pointed out that more men work than women in most countries, and they get paid more for similar work. In many countries, girls and women have less access to education, health and finance than boys and men.

\subsection{Model Specification}

The aim of the study was to investigate the differences in household income based on the gender and marital status of the head of household. An ANOVA (Analysis of Variance) model is estimated as this regression model has qualitative explanatory variables only (Gujarati \& Porter, 2009:283). A separate ANOVA model was run for marital status before combining marital status and gender. The model was specified as follows

$$
Y=\alpha_{0}+\alpha_{1} D_{1}+\cdots \alpha_{n} D_{n}+\beta_{j} D_{j}+e_{i}
$$

Where $\mathrm{Y}$ is household income, $\alpha_{0}$ is the intercept term $\alpha_{1} \ldots \alpha_{n}$ are the coefficients for the different marital status categories that are represented by $D_{1}$ to $D_{n}$. Marital status responses had seven categories namely, never married, married, divorced, separated, widowed, cohabiting and child. In the sample there were no children so the child category was removed. Married and separated were further grouped together as one group, the basic justification of grouping married and separated as one category was that separated people are by definition still married and most circumstances financial obligations remain unchanged between the partners. The final marital status variable had 4 categories namely never married, Married, Divorced and widowed. $\beta_{j} D_{j}$ are the coefficient and the dummy for gender respectively.

The dummy variables are there defined as follows; $D_{1}$ dummy variable for never married defined as 1 for never married and 0 all other values. $D_{2}$ dummy for Marred defined as 1 for married and 0 all other values. $D_{3}$ dummy variable for divorced defined as 1 for divorced and 0 all other values. $D_{4}$ dummy variable for widowed defined as 1 for widowed and 0 otherwise. In an Anova model or any categorical variable, $\mathrm{n}-1$ dummy variables are need for a categorical variable with $n$ categories. In this case 3 dummy variables are used for marital status with 4 categories. The dummy for gender is defined as 1 for female and 0 for male.

The model to be estimated will therefore take the following form

$$
Y=\alpha_{0}+\alpha_{1} \text { never Married }+\alpha_{2} \text { Divorced }+\alpha_{3} \text { Widowed }+\beta_{1} \text { Gender }+e_{i}
$$

The forth category which is Married is therefore the reference category meaning that all the coefficients will be compared to married who will take the value of the coefficient.

\section{Results and discussion}

Table 1 are the frequencies of the marital status distribution in the sample, this helps paint a picture of the percentage distribution of the different categories. The biggest group is those that were never married. This indicates that a large number 
of heads of households are either young or that marriage is not common which is in agreement with what was discussed in the literature as to the popularity of marriage in the $21^{\text {st }}$ century (STATSSA 2014). Those that are married however are also a sizeable percentage.

Table1: Frequencies for Marital Status

\begin{tabular}{|l|l|c|c|}
\hline \multicolumn{2}{|l|}{} & Frequency & Percentage \\
\hline \multirow{4}{*}{ Valid } & Never married & 107 & $36.4 \%$ \\
\cline { 2 - 4 } & Married and living together & 88 & $29.9 \%$ \\
\cline { 2 - 4 } & Divorced & 16 & $5.4 \%$ \\
\cline { 2 - 4 } & Widowed & 83 & $28.2 \%$ \\
\cline { 2 - 4 } & Total & 294 & $100 \%$ \\
\hline \multicolumn{2}{|l|}{ Total } & 294 & 100.0 \\
\hline
\end{tabular}

Source: Survey Data

Table 2 presents the gender distribution in the sample. Although one can argue that there is almost an equal representations, the figures show that there were more females taking up 54.3 percent compared to the male participants who took up the remaining 45.7 percent of the sample.

Table 2: Gender distribution

\begin{tabular}{|l|l|c|c|}
\hline \multicolumn{2}{|c|}{} & Frequency & Percentage \\
\hline \multirow{3}{*}{ Valid } & Males & 137 & $45.7 \%$ \\
\cline { 2 - 4 } & Female & 163 & $54.3 \%$ \\
\cline { 2 - 4 } & Total & 300 & $100.0 \%$ \\
\hline
\end{tabular}

Source: Survey Data

The number distribution of the sample between males and females is balanced enough so that the numbers in the marital status categories should not be skewed due to under representation of one category. Table 3 is a cross-tabulation of gender and marital status to see which category between males and females is more represented in the married category. The results in table 3 indicate that there is a difference in the representation of males and females in the group. Table 4 also confirms that there is a significant difference between the marital status of males and females in the sample. A big representation amounting to $85.2 \%$ within the married or living together are males, and females only take up $14.8 \%$ of the living together or married. This only means that in the households where there is both partners, it was the males that were reported as the head of household. In the $14.8 \%$ of the married or living together, the head of household was the female, these could be households where the female is a bread winner or where both partners are female. 
Table 3: Gender Head and marital status association

\begin{tabular}{|c|c|c|c|c|c|c|}
\hline & \multicolumn{4}{|c|}{ Marital status } & \multirow[b]{2}{*}{ Total } \\
\hline & & $\begin{array}{l}\text { Never } \\
\text { Married }\end{array}$ & $\begin{array}{l}\text { Married } \\
\text { or Living } \\
\text { together }\end{array}$ & Divorced & Widowed & \\
\hline \multirow{4}{*}{ Males } & Count & 23 & 75 & 5 & 32 & 135 \\
\hline & $\begin{array}{c}\text { \% within Gender } \\
\text { Head }\end{array}$ & $17.0 \%$ & $55.6 \%$ & $3.7 \%$ & $23.7 \%$ & $100.0 \%$ \\
\hline & $\begin{array}{l}\% \text { within New } \\
\text { Marital status }\end{array}$ & $21.5 \%$ & $85.2 \%$ & $31.3 \%$ & $38.6 \%$ & $45.9 \%$ \\
\hline & $\%$ of Total & $7.8 \%$ & $25.5 \%$ & $1.7 \%$ & $10.9 \%$ & $45.9 \%$ \\
\hline \multirow{4}{*}{ Female } & Count & 84 & 13 & 11 & 51 & 159 \\
\hline & $\begin{array}{c}\text { \% within Gender } \\
\text { Head }\end{array}$ & $52.8 \%$ & $8.2 \%$ & $6.9 \%$ & $32.1 \%$ & $100.0 \%$ \\
\hline & $\begin{array}{l}\% \text { within New } \\
\text { Marital status }\end{array}$ & $78.5 \%$ & $14.8 \%$ & $68.8 \%$ & $61.4 \%$ & $54.1 \%$ \\
\hline & $\%$ of Total & $28.6 \%$ & $4.4 \%$ & $3.7 \%$ & $17.3 \%$ & $54.1 \%$ \\
\hline \multirow{4}{*}{ Total } & Count & 107 & 88 & 16 & 83 & 294 \\
\hline & $\begin{array}{c}\text { \% within Gender } \\
\text { Head }\end{array}$ & $36.4 \%$ & $29.9 \%$ & $5.4 \%$ & $28.2 \%$ & $100.0 \%$ \\
\hline & $\begin{array}{l}\% \text { within New } \\
\text { Marital status }\end{array}$ & $100.0 \%$ & $100.0 \%$ & $100.0 \%$ & $100.0 \%$ & $100.0 \%$ \\
\hline & $\%$ of Total & $36.4 \%$ & $29.9 \%$ & $5.4 \%$ & $28.2 \%$ & $100.0 \%$ \\
\hline
\end{tabular}

Source: Calculations from survey data

The household heads that reported to be in the 'never married' category were predominantly females, taking up $78.5 \%$ compared to only $21.5 \%$ for males. This revelation needs a deeper digging to understand as to why there are more female single headed households compared to male single headed households. Would it mean that men do not head household as single parents? If that is the case why? Is it the case that when they are not married males live under some head until they marry? This number should not be confused with separated or divorced who are in their own category. There are more questions to this results than there are answers. This could be the whole explanation behind the vulnerability of women falling into poverty than men. Since married people are more likely to have a higher income and escape poverty, and more men are likely to live in a married situation than female, then it follows that women are indeed more likely to fall into poverty. The reasons could be the same as those used to explain higher incomes in households where the head of household is married. 
Table 4: Chi-Square Test

\begin{tabular}{|lr|c|c|}
\hline & Value & $\begin{array}{c}\text { Degrees } \\
\text { of freedom }\end{array}$ & $\begin{array}{c}\text { Asymptotic Significance } \\
\text { (2-sided) }\end{array}$ \\
\hline Pearson Chi-Square & $83.655^{\mathrm{a}}$ & 3 & .000 \\
\hline Likelihood Ratio & 89.985 & 3 & .000 \\
\hline Linear-by-Linear Association & 1.231 & 1 & .267 \\
\hline N of Valid Cases & 294 & \multicolumn{2}{|l}{} \\
\hline a. 0 cells $(0.0 \%)$ have expected count less than 5. The minimum expected count is 7.35. \\
\hline
\end{tabular}

Source: Calculations from survey data

The Pearson Chi-Square Test reported in table 4 confirms the differences in marital status between males and females in the data. A p-value of 0.000 means that we reject the null hypothesis of no significant difference between the gender categories in terms of marital status, and conclude that there is a significant difference in marital status between males and females.

Table 5: Regression results of the ANOVA model

\begin{tabular}{|c|c|c|c|c|c|}
\hline \multicolumn{6}{|c|}{ Coefficients } \\
\hline \multirow{2}{*}{ Model } & \multicolumn{2}{|c|}{ Unstandardized Coefficients } & \multirow{2}{*}{$\begin{array}{c}\text { Standardized } \\
\text { Coefficients } \\
\text { Beta }\end{array}$} & \multirow{2}{*}{$\mathbf{t}$} & \multirow{2}{*}{ Sig. } \\
\hline & B & Std. Error & & & \\
\hline (Constant) & 1622.250 & 316.305 & & 5.129 & .000 \\
\hline Divorced & 270.503 & 634.221 & .024 & .427 & .670 \\
\hline $\begin{array}{l}\text { Married or living } \\
\text { together }\end{array}$ & 1707.525 & 381.598 & .310 & 4.475 & .000 \\
\hline Never Married & 49.339 & 339.081 & .009 & .146 & .884 \\
\hline $\begin{array}{c}\text { Gender (Female } \\
\text { head) }\end{array}$ & -623.096 & 318.872 & -.124 & -1.954 & .052 \\
\hline \multicolumn{6}{|c|}{ a. Dependent Variable: Household total income } \\
\hline
\end{tabular}

Source: Calculations from survey data

The results of the Anova regression model are reported in table 5. The regression is known as an Anova or analysis of variance regression because all the explanatory variables are categorical variables, meaning that the regression basically looks at how the dependent variable varies across the categories of the explanatory variable(s). It can also be calculated to see how much each category would have as an average in terms of the dependent variable, hence in the case average household income based on the marital status and gender of the head of the household. 
The category "Widowed" is not entered in the regression based on the rule of how to deal with categorical variables in a regression. Given a variable with N categories, then $\mathrm{N}-1$ dummy variables are entered in the regression. If all $\mathrm{N}$ categories were to be entered it would create a problem of perfect multicollinearity. So for marital status, widowed is not entered and hence it takes the value of the constant, but also on gender, males are not entered based on the same N-1 principle, and hence widowed male head of households take the value of the constant. In this case the results show that widowed male head of households have an average income of R1622.25. On the other hand widowed female heads of household on average have a monthly income of R999.15 (R1622.25-R623.096). A summary of the average incomes are therefore as follows;

Table 6: Average monthly incomes for the marital status categories by gender

\begin{tabular}{|l|r|}
\hline Widowed female head of household & R999.15 \\
\hline Never Married Females & $\mathrm{R} 1048.51$ \\
\hline Divorced Females & $\mathrm{R} 1269.66$ \\
\hline Widowed Male head of household & $\mathrm{R} 1622.25$ \\
\hline Never Married Males & $\mathrm{R} 1671.60$ \\
\hline Divorced males & $\mathrm{R} 1892.75$ \\
\hline Married or living together Females & $\mathrm{R} 2706.69$ \\
\hline Married or living together Males & $\mathrm{R} 3329.78$ \\
\hline
\end{tabular}

Source: Calculations from the regression in table 5

Table 6 presents the monthly average incomes for the households with heads belonging to the different marital status and gender categories. The lowest earners are the widowed female heads of households, and the highest earners are the male married or living together heads of households. The summary of results confirms the hypothesis that marriage is associated with higher levels of household income whether the head is male or female. This could be explained by the same explanation as that given in Helsing, et al. (1981:808) and Zick and Smith, (1991) that its people with good income that are selected into marriages and not necessarily marriage helping people to have higher income. The higher income among the married could also be explained by the fact that it is combined income from the two partners in the marriage.

\section{Conclusion}

The study has revealed a number of interesting results; first that there are more single female headed households than are of male in Boipatong Township this is difficult to conclude based on this study. This idea should be narrowed to be a picture in the current sample. The fact that there are more male headed households in the married category is not surprising as men are considered a de-facto head of 
households in married couples. Although a reasonable percentage of married households reported females as the head and this may mean a movement from the traditional 'man is head' to a new definition of head, which may include the one earning the income or a higher income between the two. This also agrees with a number of studies on poverty with marital status of the head of household (Grobler, Dunga, 2014; Makhalima, Sekatane, Dunga, 2014; Meyer, Dunga, 2014).

The paper has also confirmed the perception in the literature that married people are at an advantage in terms of having on average a higher income than the other categories. The widowed females have the lowest income of all the categories. This lower income among the widows could be an indication of women that relied on their husbands to provide, as it is shown by the fact that widowed males income is higher than that of widowed women, divorced and never married women. This point to the age old understanding that women are more vulnerable than men, and that the fight for gender equality needs to continue, especially in-terms of income. The fact that married heads of households have a higher income may also be based on the fact that they have combined income from the two partners. There is need for more studies to understand the importance of marriage especially in the contemporary age where there are more divorces than there are marriages. The study raises more questions, interesting questions that make further investigations into the characteristics of these households pertinent. The study recommends more in-depth analysis of the dynamics between male and female headed households, and the relationship between marital status and incomes, taking into account the structure of the households and making comparisons in other similar townships in South Africa

\section{References}

Atkinson, K. E. (2008). An introduction to numerical analysis. John Wiley \& Sons.

Alkire, S. (2009). Multidimensional Measures of Poverty \& Well-being 1, 1-39.

Alkire, S., Foster, J. E. (2013). A Report on Mexican Multidimensional Poverty Measurement (No. 60). Oxford.

Barrett, C. B., Carter, M. R. (2006). The economics of poverty traps and persistent poverty: Empirical and policy implications. Journal of Development Studies, 42(2), 178-199. http://doi.org/10.1080/00220388.2013.785527

Brandolini, A., Magri, S., Smeeding, T. M. (2010). Asset-based measurement of poverty. Journal of Policy Analysis and Management, 29(2), 267-284. http://doi.org/10.1002/pam.20491

Chant, S. (2008). The "Feminisation of Poverty" and the "Feminisation" of AntiPoverty Programmes: Room for Revision? Journal of Development Studies, 44(2), 165-197. http://doi.org/10.1080/00220380701789810

Chant, S. H. (2006). LSE Research Online Working paper Female household headship and the feminisation of poverty : facts, fictions and forward strategies.

Dollar, D., and Kraay, A. (2000). Growth is good for the poor. Washington, DC: World Bank

Dubihlela, J., Dubihlela, D. (2014). Social Grants impact on poverty among the Female-Headed Households in South Africa: A case analysis. Mediterranean Journal of Social Sciences, 5(8), 160. 
Gove, W. R. (1973). Sex, marital status, and mortality. American Journal of Socialogy, $79,45-67$.

Grobler, W. C. J., Dunga, S. H. (2014). An Analysis of the Perceptions of Causes of Poverty among Grant Receiving and Non-Grant Receiving Households, (October), 1-9.

Helsing, K., Moyses, S., Comstock, G. (1981). Factors associated with mortality after widowhood. Amer. J. Public Health, 71(8), 802-809. Retrieved from http://ezproxy.lib.utexas.edu/login?url=http://search.ebscohost.com/login.aspx? direct=true\&db=psyhref\&AN=AJPH.GA.HJB.HELSING.FAMAW

Kinoshita, Y., Guo, F. (2015). What can boost female labor force participation in Asia?. International Monetary Fund

Kobrin, F. E., Hendershot, G. (1977). Do family ties reduce mortality? Evidence from the United States, 1966-1968. Journal of Marriage and Family, 39, 737-745.

Makhalima, J. L., Sekatane, M. B., Dunga, S. H. (2014). Determinants of Child Poverty in a South African Township: A Case of Boipatong Township. Mediterranean Journal of Social Sciences, 5(1). http://doi.org/10.5901/mjss.2014.v5n1p235

Mergenhagen, P. M., Lee, B. A., Gove, W. R. (1985). Till death do us part: Recent changes in the relationship between marital status and mortality. Sociology and Social Research, 70, 53-56.

Meyer, B. D., Sullivan, J. X. (2012). Identifying the Disadvantaged: Official Poverty, Consumption Poverty, and the New Supplemental Poverty Measure. Journal of Economic Perspectives, 26(3), 111-136. http://doi.org/10.1257/jep.26.3.111

Meyer, D.F., Dunga, S.H. (2014). The Determinants of Life Satisfaction in a LowIncome, Poor Community in South Africa. Mediterranean Journal of Social Sciences, 5(13). http://doi.org/10.5901/mjss.2014.v5n13p163

Ravallion, M. (1996). Issues in measuring and modelling poverty.

Ravallion, M. (2001). Growth, inequality and poverty: looking beyond averages. World development, 29(11), 1803-1815.

Sekhampu, T. J. (2013). Determination of the factors affecting the food security status of households in Bophelong, South Africa. The International Business \& Economics Research Journal (Online), 12(5), 543.

Sen, A. (1981). Poverty and famines: an essay on entitlement and deprivation. Oxford University. http://doi.org/10.1016/0147-5967(83)90075-6

Trovato, F., Lauris, G. (1998). Marital status and mortality in Canada: 1951-1981. Journal of Marriage and the Family, 51, 907-922.

Zick, C. D., \& Smith, K. R. (1991). Marital Transitions, Poverty, and Gender Differences in Mortality. Journal of Marriage and Family, 53(2), 327-336. http://doi.org/10.2307/352902

Society at a Glance 2016, OECD Publishing, Paris; Philipov, D, and J. Dorbritz. (2003) Demographic consequences of economic transition in countries of Central and Eastern Europe. Strasbourg: Council of Europe Publishing

Woolard, I., \& Klasen, S. (2005). Determinants of income mobility and household poverty dynamics in South Africa. Journal of Development Studies, 41(5), 865897. 